\title{
Efektifitas dan Kandungan Fraksi Aktif Metanol Daun Sirih Hijau (PIPER Betle L) sebagai Antibakteri Salmonellatyphi
}

\author{
Rosita Mangesa $^{1^{*}, \text { Febiayu Aloatuan }^{2}}$ \\ ${ }^{1}$ Pendidikan Biologi, Universitas Iqra Buru, Namlea, Indonesia \\ ${ }^{2}$ Pendidikan Biologi, STKIP Gotong Royong Masohi, Indonesia \\ "Email: rositamangesa5@gmail.com \\ Received: April 17 $7^{\text {th }}$,2019. Accepted: June 29 ${ }^{\text {th }}, 2019$. Published: June $30^{\text {th }}, 2019$
}

\begin{abstract}
The content of secondary metabolic compounds in plants is often used as antibiotics and to obtain secondary metabolic compounds extraction and fractionation processes are carried out. This study aims to determine, (1) the content of flavonoids and flavonoid levels in the fraction of samples of green betel leaves; (2) the most active fraction in inhibiting the activity of Salmonella typhi bacteria; (3) types of compounds found in the active fraction and molecular structure. This research is an experimental research where the results of the study will be described as a whole. The results of the analysis showed that of the four fractions obtained from green betel leaf samples, three of them contained flavonoid compounds with the highest flavonoid content in the M1 fraction which was equal to $51.4108 \% \mathrm{~b} / \mathrm{b}$. Antibacterial test results showed that the best fraction of green betel leaf samples was the methanol fraction at a concentration of $62.2 \mu \mathrm{g} / \mathrm{ml}$ having a inhibition zone of $4.3 \mathrm{~mm}$ with the highest molecular weight found on the Galic acid compound and its molecular formula C7H6O5.
\end{abstract}

Keywords: Active Fraction; Antibacterial; Green Betel Leaves; Salmonella typhy

\begin{abstract}
Abstrak
Kandungan senyawa metabolisme sekunder pada tanaman sering digunakan sebagai bahan antibiotik dan untuk mendapatkan senyawa metabolisme sekunder dilakukan proses ekstraksi maupun fraksinansi. Penelitian ini bertujuan untuk mengetahui, (1) kandungan flavonoid beserta kadar flavonoid pada fraksi dari sampel daun sirih hijau; (2) fraksi yang paling aktif dalam menghambat aktifitas bakteri Salmonella typhi; (3) jenis senyawa yang terdapat pada fraksi aktif dan struktur molekulnya. Penelitian ini merupakan penelitian eksperimen dimana hasil penelitian akan dideskripsikan secara keseluruhan. Hasil analisis menunjukan dari empat fraksi yang diperoleh dari sampel daun sirih hijau tiga diantaranya mengandung senyawa flavonoid dengan kadar flavonoid tertinggi terdapat pada fraksi $\mathrm{M}_{1}$ yaitu sebesar 51,4108 \% b/b. Hasil pengujian antibakteri menunjukan bahwa fraksi terbaik dari sampel daun sirih hijau adalah fraksi metanol pada konsentrasi $62,2 \mu \mathrm{g} / \mathrm{ml}$ memiliki zona hambat sebesar 4,3 mm dengan berat molekul tertinggi terdapat pada senyawa Galic acid dan rumus molekulnya $\mathrm{C}_{7} \mathrm{H}_{6} \mathrm{O}_{5}$.
\end{abstract}

Kata Kunci: Fraksi Aktif; Antibakteri; Daun Sirih Hijau; Salmonella typhi

\section{PENDAHULUAN}

Saat ini telah banyak jenis mikroorganisme yang dapat menyebabkan penyakit maupun infeksi, salah satunya yaitu bakteri Salmonella typhi yang merupakan bakteri jenis gram negative dengan ukuran 2-4 mikrometer $X$ 0,5-0,8 mikrometer, dan berbentuk menyerupai batang serta memiliki flagel peritrik sebagai alat gerak. Bakteri Salmonella typhi menyebabkan terjadinya penyebab demam tifoid (Moch, 2014; Nirwana, 2013; Nita, 2013).

Penanganan dari penyakit demam tifoid ini yaitu dengan pemberian antibiotik. Penggunaan antibiotik secara tidak teratur dan tidak tepat dapat menyebabkan bakteri 
menjadi resisten yang disebabkan oleh adanya perubahan genetik, salah satunya yaitu bakteri Salmonella typhi yang mana pada 1989 terjadi resistensi terhadap tiga antibiotic diantaranya antibiotic kloramfenikol, kontrimoksasol, dan amoksilin yang mana hal ini ditemukan secara luas pada daerah India, Cina, Pakistan dan bahkan menyebar hingga wilayah Afrika Selatan dan Timur Tengah (Nirwana, 2013).

Pada beberapa tumbuhan terdapat senyawa bioaktif yang dapat dimanfaatkan sebagai antibiotik, dengan adanya kasus resistensi bakteri memberikan peluang untuk mengoptimalkan senyawa bioaktif dari tumbuhan (A, Fatimawali, \& I, 2012; Ayu, 2013). Saat ini daun sirih hijau telah banyak dikenal dan digunakan sebagai obat antibakteri, serta merupakan tumbuhan dari jenis piperaceae. Umumnya daun sirih memiliki kandungan kavikol, karvakol, kavibetol, kariovilem, 1-4,2\% hidroksikavikol, terpene, asam askorbat, fenil propane, enzim diastase 0,8-1,8\%, serkuiterpena, enzim katalase, metal eugenol, vitamin A, B, C, asam-asam lemak gula, dan pati. Berdasarkan hasil penelitian 82,8\% kandungan minyak atsiri terdiri dari senyawa fenol dan 18,2\% adalah kandungan senyawa non fenol, yang mana senyawa antibaktgeri yang dihasilkan dapat bersifat gemnisidal, fungisidal dan bakterisidal. Untuk memperoleh senyawa bioaktif atau senyawa metabolisme sekunder dapat dilakukan dengan cara ekstraksi dan fraksinasi, namun senyawa bioaktif atau metabolisme sekunder yang dihasilkan bergantung dari peoses ekstraksi maupun fraksinasi.

Berdasarkan beberapa penelitian yang telah dilakukan sebelumnya, banyak penelitian yang membahas mengenai kandungan fraksi aktif methanol daun sirih hijau (Hafida, Ekiyantini, \& Sri, 2012; Haryun, WIdodo, \& Sudjarwo, 2017; Moch, 2014; Syahrinastiti, A, Aziz, \& Lili, 2015; Ulviani, Yusriadi, \& Khaerati, 2016; Widjaya, Retnani, \& Hermana, 2018; Wilis \& Andriani, 2017) Serta penelitian mengenai antibakteri Salmonella typhi (Moch, 2014; Nirwana, 2013; Nita, 2013). Namun, belum adanya penelitian yang mengembangkan lembar aktivis matematika berorientasi pendekatan saintifik untuk siswa SD

Berdasarkan kajian terdahulu keterbaruan penelitian ini terletak pada efektivitas dan kandungan fraksi aktif methanol daun sirih hijau sebagai antibakteri Salmonella typhi. Maka, tujuan penelitian ini adalah mengetahui (1) kandungan flavonoid beserta kadar flavonoid pada fraksi dari sampel daun sirih hijau; (2) fraksi yang paling aktif dalam menghambat aktifitas bakteri Salmonella typhi; (3) jenis senyawa yang terdapat pada fraksi aktif dan struktur molekulnya

\section{METODE PENELITIAN}

Penelitian ini merupakan penelitian eksperimen laboraturium, dengan sampel daun sirih hijau dengan variabel fraksi dan efektifitas daya hambat.

Alat yang digunakan adalah Blender, Erlenmeyer, Timbangan, Kantong Plastik, Labu Ukur, Gelas Beker, Spatula, Gelas Ukur, Rotary Evaporator, Neraca Analitik, Corong Pisah, Pipet, Lemari Es, Mikropipet, Batang Pengaduk, Tabung Reaksi, Hot Plat, Spektrofotometer, Incubator, Autoclave, Mistar, Petri, LCMS. Bahan yang digunakan: Simplisia Daun Sirih Hijau, Pelarut Diantaranya Metanol, Etil Asetat, N-Heksan, Air, $\mathrm{Alcl}_{3}$ 5\%, Naoh 40\%, Aluminium Klorida 10\%, Aquades, Media SS, Kalium Asetat.

\section{Cara kerja}


Ekstraksi dan Fraksinasi: Simplisia dari daun sirih hijausebanyak 450 gr dimaserasi dengan metanol sebanyak $1000 \mathrm{ml}$, kemudian disaring dan dipekatkan dengan rotary evaporator yang selanjutnya dimaserasi kembali sebanyak tiga kali. Selanjutnya hasil ekstraksi yang diperoleh dipartisi lagi secara bertingkat dengan menggunakan pelarut n-heksan dengan perbandingan 1:1 yang kemudian dimasukkan kedalam corong pisah. Hasil fraksi yang diperoleh akan dipekatkan dan sisa dari mmetanol + air dipartisi lagi dengan larutan etil asetat, kemudian hasil sisa dari fraksi dipartisi lagi dengan larutan kloroform. Fraksi-fraksi yang telah didapatkan selanjutnya akan dipekatkan.

Skrining Senyawa Flavonoid dan Pengujian Kadar Flavonoid: $1 \mathrm{ml}$ sampel ditambahkan $1 \mathrm{ml}$ etanol 95\%, 0,5 ml asam kloroda, $100 \mathrm{mg}$ serbuk $\mathrm{Mg}$ kemudian diamati perubahan warna yang terjadi. Apabila warna yang terlihat adalah warna jingga, maka hal ini menunjukan senyawa flavonoid golongan khalkon, auron atau flavon. Sampel yang mengandung senyawa flavonoid akan diuji kadarnya dengan cara dibuatkan kurva kalibrasi dengan quersitin sebagai pembanding, yang kemudian sampel akan diuji kadarnya dengan spktrofotometer UV-VIS pada panjang gelombang maksimum yaitu $438 \mathrm{~nm}$, dan dihitung kadar flaonoidnya dengan rumus sebagai berikut:

Keterangan:

$$
\mathrm{FT}=\frac{C \times V \times F \times 10^{-6}}{m} \times 100 \%
$$

$$
\begin{array}{ll}
\mathrm{FT} & =\text { jumlah flavonoid } \\
\mathrm{C} & =\text { kesetaraan quersetin } \\
\mathrm{V} & =\text { volume total ekstrak metanol } \\
\mathrm{F} & =\text { factor } \text { pengenceran } \\
\mathrm{m} & =\text { berat sampel }
\end{array}
$$

Pengujian antibakteri: Tiap sampel yang mengandung senyawa flavonoid diencerkan dengan twin 20 sehingga menjadi beberapa kosentrasi diantaranya 248,8 $\mu \mathrm{g}$, $124,4 \mu \mathrm{g}$, dan 62,6 $\mu \mathrm{g}$. kemudian bakteri Salmonella typhi diswab pada bagian atas permukaan media SS yang telah dibuatkan sumuran yang kemudian diisi dengan fraksi yang telah diencerkan selanjutnya dinkubasi selama 24 jam dengan suhu $37^{\circ} \mathrm{C}$ dan diamati zona daya hambatnya.Fraksi yang memiliki daya hambat terbesar yang kemudian diuji kandungannya menggunakan alat LC-MS.

\section{HASIL PENELITIAN DAN PEMBAHASAN}

\section{Hasil Analisis Skrining Senyawa Flavonoid Dan Kadar Flavonoid.}

Berdasarkan fraksi yang telah dikumpulkan diperoleh empat jenis fraksi yang keseluruhan fraksi tersebut mengandung senyawa flavonoid. Berikut merupakan Tabel 1 hasil skrining senyawa flavonoid.

Tabel 1. Analisis Skrining Senyawa Flavonoid

\begin{tabular}{ccccc}
\hline Jenis Sampel & Jenis fraksi & Warna Awal & Warna Akhir & Hasil \\
\hline Daun sirih hijau & Fraksi M & Hijau & Kuning & + \\
& fraksi M & Hijau & Kuning & + \\
& Frakis $M_{3}$ & Hijau & Kuning & + \\
& Fraksi M & Coklat muda & Kuning & + \\
\hline
\end{tabular}


Berdasarkan fraksi yang diuji mengandung senyawa flavonoid selanjutnya diukur kadar senyawa flavonoidnya dengan menggunakan alat spektrofotometer. Berikut merupakan gambar kadar flavonoid dari beberapa fraksi.

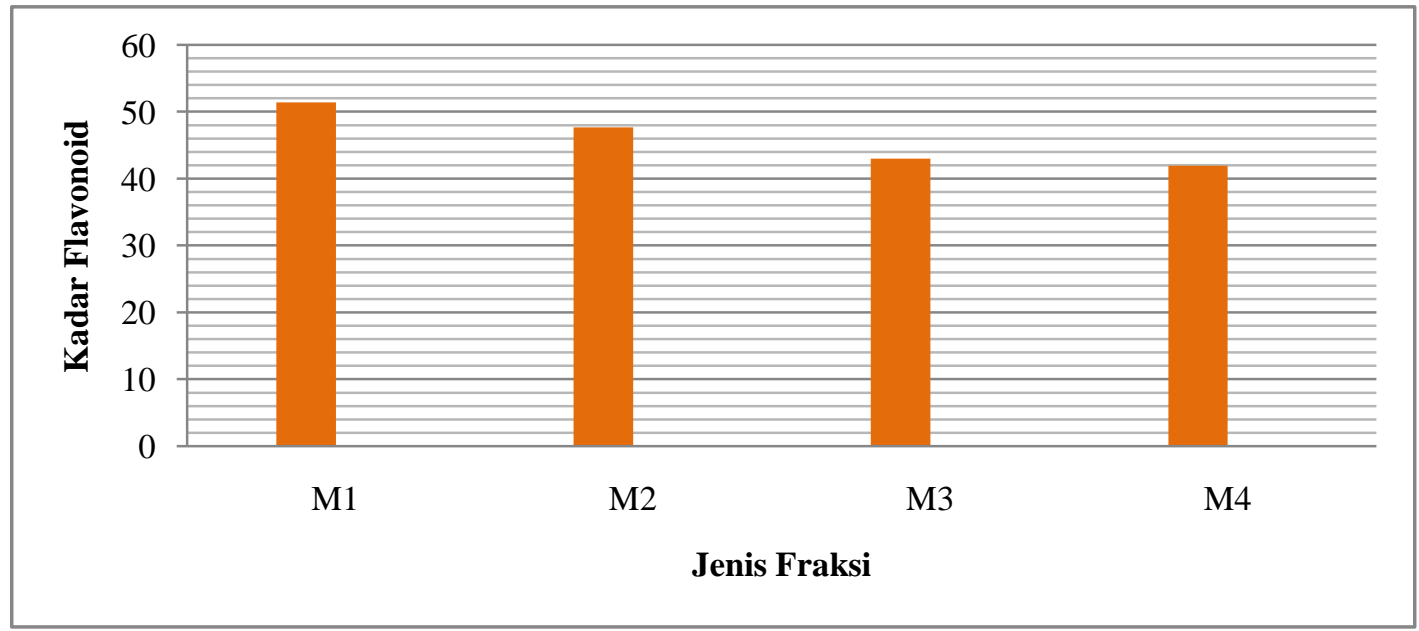

Gambar 1. Kadar Flavonoid

Berdasarkan Gambar 1. kadar flavonoid terlihat bahwa kadar sampel $\mathrm{M}_{1}$ lebih tinggi dibandingkan fraksi yang lain dengan kadar flavonoid sebesar 51,4108 \% b/b dan kadar flavonoid terendah pada fraksi $\mathrm{M}_{4}$ yaitu sebesar 41,9535 \% b/b.

\section{Efektifitas Antibakteri}

Dari hasil analisis efektifitas antibakteri unuk perlakuan $\mathrm{M}_{1}, \mathrm{M}_{2}$, dan $\mathrm{M}_{3}$ terlihat bahwa semakin tinggi konsentrasi maka maka daya hambatnya akan semakin besar. Pada fraksi $\mathrm{M}_{1}$ dengan konsentrasi tinggi 248,8 $\mu \mathrm{g}$ memiliki daya hambat sebesar $6.6 \mathrm{~mm}$, fraksi $\mathrm{M}_{2}$ dengan konsentrasi tinggi 248,8 $\mu \mathrm{g}$ memiliki daya hambat sebesar 3,16 mm, fraksi $\mathrm{M}_{3}$ dengan konsentrasi tinggi $248,8 \mu \mathrm{g}$ memiliki daya hambat sebesar 6,5 $\mathrm{mm}$, namun hal tersebut tidak berlaku pada fraksi sirih hijau $\mathrm{M}_{4}$ dimana dengan konsentrasi tinggi $248,8 \mu \mathrm{g}$ memiliki daya hambat sebesar $3,5 \mathrm{~mm}$ hasilnya justru lebih rendah bila dibandingkan dengan konsentrasi 62,2 $\mu \mathrm{g}$. Berikut merupakan diagram aktivitas antibakteri dari fraksi daun sirih hjau terhadap bakteri Salmonella thypi.

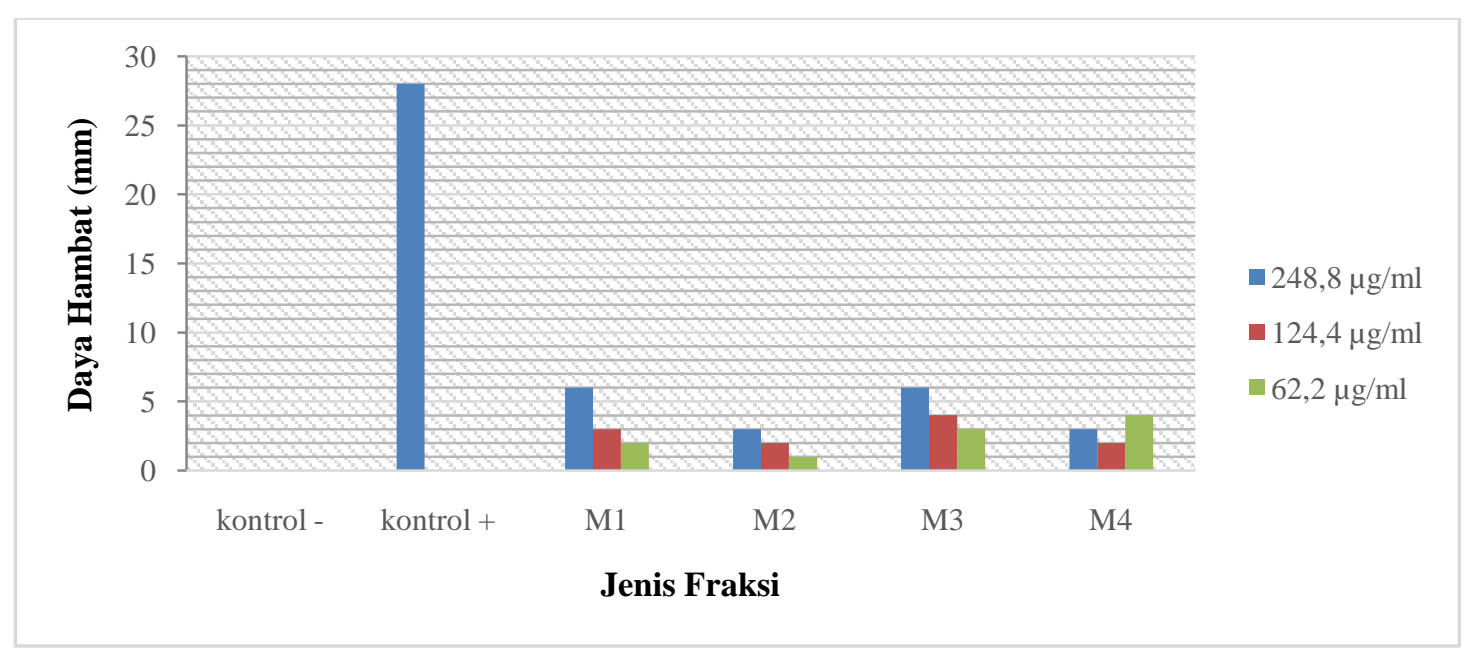

Gambar 2. Diagram aktifitas antibakteri 
Berdasarkan tingkat kekuatan daya hambat maka konsentrasi rendah yang memiliki daya hambat terbesar merupakan fraksi terbaik, dan hal tersebut terdapat pada fraksi $\mathrm{M}_{4}$ pada konsentrasi yang kecil $(62,2 \mu \mathrm{g} / \mathrm{ml})$ memiliki daya hambat yang besar yaitu $4,33 \mathrm{~mm}$.

\section{Jenis Senyawa Dan Struktur Dari Fraksi Aktif}

Fraksi M4 merupakan fraksi yang dianggap terbaik sehingga dilanjutkan pada pengujian jenis senyawa serta struktur kimianya.Dari hasil chromatogram terlihat 61 jenis senyawa yang terdeteksi pada fraksi M4 dengan komposisi dan berat molekul yang berbeda-beda.Berikut merupakan gambaran grafik chromatogram dan molekul dari tiap senyawa yang terdapat pada fraksi $\mathrm{M}_{4}$.

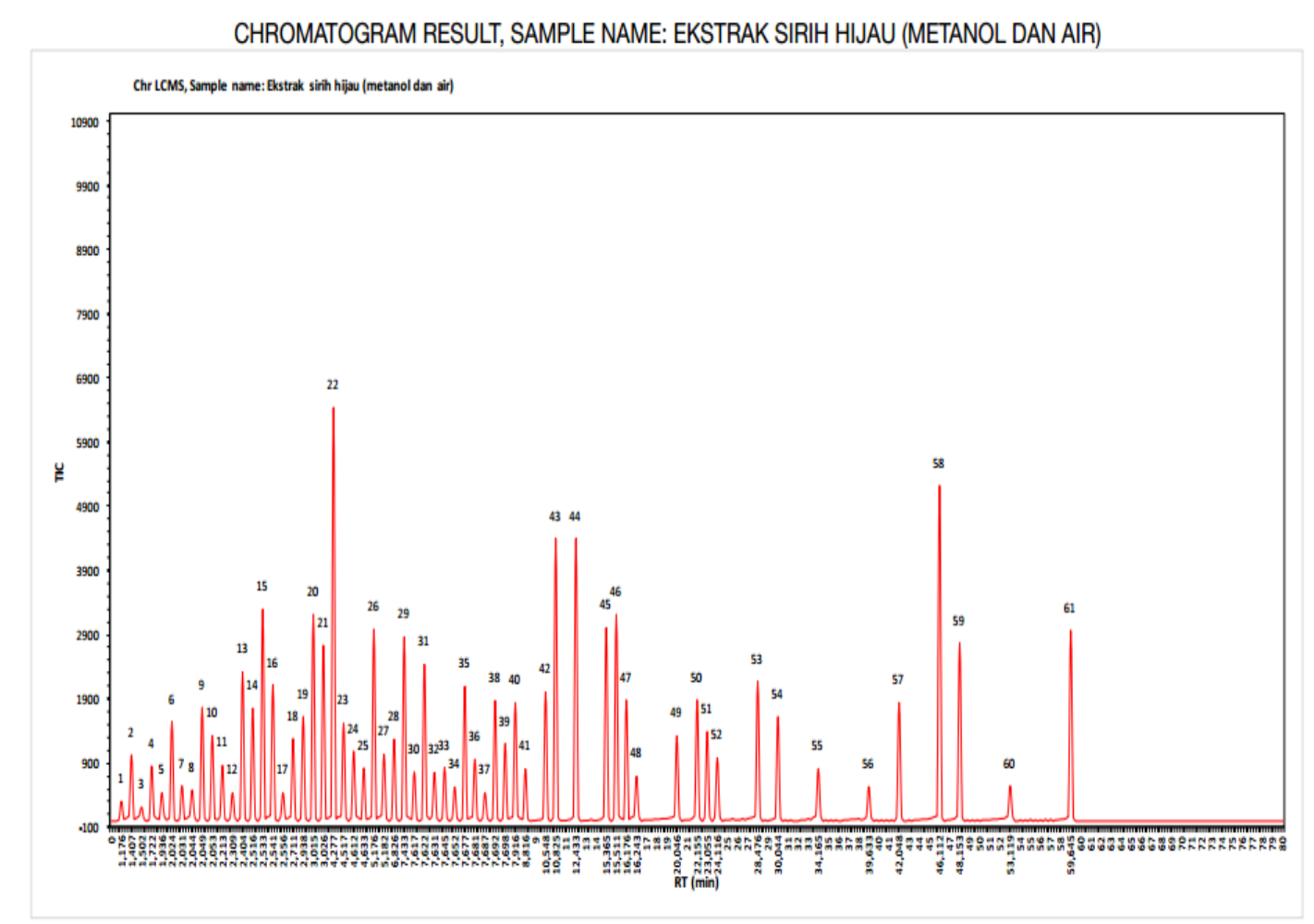

Gambar 3. Grafik Chromatogram Fraksi Metanol

Komposisi terbanyak terlilhat pada peak nomor 22 yaitu senyawa Gallic acid dengan bentuk struktur molekul sebagai berikut.<smiles>O=C(O)c1cc(O)c(O)c(O)c1</smiles>

$\mathrm{m} / \mathrm{z}: 170.02(100.0 \%), 171.02$ (7.6\%), $172.03(1.3 \%)$

Gambar 4. Struktur Galic Acid 
Gallic acid atau asam galat merupakan turunan dari asam hidroksibenzoat dan termasuk dalam golongan asam fenol sederhana. Senyawa fenol sendiri merupakan senyawa yang memiliki aktivitas sebagai antibakteri.

Berdasarkan hasil analisis kadar flavonoid terlihat bahwa kandungan tertinggi senyawa flavonoid yaitu terletak pada fraksi $\mathrm{M}_{1}$ sebesar 75,7305 \% b/b dan kadar flavonoid terendah pada fraksi $\mathrm{M}_{4}$. Hal ini menunjukkan bahwa proses fraksinasi untuk senyawa flavonoid lebih tertarik keluar pada pelarut n-heksan.

Namun efektifitas antibateri yang paling baik terlihat pada fraksi $\mathbf{M}_{4}$ dimana pada konsentrasi yang sangat kecil fraksi $\mathrm{M}_{4}$ memiliki daya hambat yang lebih besar. Perbedaan besarnya zona hambat antar fraksi disebabkan karena adanya kandungan senyawa yang terdapat pada masing-masing fraksi berbeda-beda dimana komponen senyawa yang terdapat pada tiap fraksi berdasarkan jenis pelarutnya, yang mampu menarik senyawa berdasarkan tingkat kepolarannya. Hal ini sejalan degan pendapat Nilamsari yang menyatakan bahwa selain komponen senyawa aktif ada bebrapa hal yang mempengaruhi besar kecilnya zona hambat yang merupakan variable antibakteri antara lain konsentrasi bahan, jumlah mikroba, suhu, waktu, jenis mikroba, $\mathrm{pH}$, dan bahan organik pelarut(Tri, Tantin, \& Aju, 2012).

Jika dilihat dari kadar flavonoid terbanyak terdapat pada fraksiM $\mathrm{M}_{1}$ namun hal tersebut tidak menjamin bahwa fraksi $\mathrm{M}_{1}$ lebih efektif karena pada konsentrasi terkecil zona hambat pada fraksi $\mathbf{M}_{1}$ lebih kecil dibandingkan fraksi $\mathbf{M}_{4}$. Hal ini disebabkan oleh banyaknya senyawa antimikroba pada fraksi metanol selain senyawa flavonoid yang lebih kuat dalam menghambat pertumbuhan bakteri Salmonella thypi. Banyaknya senyawa antimikroba pada fraksi metanol karena metanol merupakan plarut yang dapat melarutkan hampir semua senyawa metabolisme sekunder.

Keseluruhan fraksi dapat menghambat pertumbuhan bakteri Salmonella thypi karena salah satu kandungan dari fraksi-fraksi tersebut adalah senyawa flavonoid. Senyawa flavonoid sendiri merupakan senyawa yang memiliki peran sebagai antibakteri, dan memiliki mekanisme kerja antibakteri yaitu mengganggu permeabilitas membran sel bakteri, dimana sebagai pelindung membrane sel dan sitoplasma tersusun atas $70 \%$ fosfolipid yang merupakan struktur dasar dari membrane protein sebanyak 30\%, sehingga terganggunya fosfolipid dari membrane sel menyebabkan permeabilitas membrane yang diikut kerusakan membrane dan keluarnya metabolit seluler seperti protein, asam nukleat dan ion-ion logam $\mathrm{Ca}^{2+}$ dan $\mathrm{K}^{+}$, selain itu senyawa aktif terhadap membrane sel dapat menyebabkanterjadinya denaturasi protein dan lisisnya sel bakteri. Hal ini sejalan dengan pendapat Roslizawaty yang menyatakan bahwa kemampuan flavonoid sebagai antibakteri diduga Karena senyawa flavonoid membentuk kompleks dengan protein ekstraseluler, mengaktivasi enzim, dan merusak membrane sel. Flavonoid sendiri berfugsi sebagai antibakteri dengan cara membentuk senyawa kompleks terhadap protein ekstraseluler yang menggaggu integritas membrane sel bakteri(Roslizawaty, Ramadani, Fakhrurrazi, \& Herrialfian, 2013).

Berbeda dari fraksi lainnya yang semakin tinggi konsentrasi semakin besar zona hambatnya, fraksi $\mathrm{M}_{4}$ dengan konsentrasi tinggi justru memiliki zona hambat lebih besar hal ini kemungkinan disebabkan oleh beberapa faktor antara lain terjadinya fluktasi yang disebabkan oleh bahan aktif yang memiliki mekanisme berbeda, perbedaan kecepatan difusi senyawa antibakteri pada media agar, dan jumlah mikroba, yang mana pada penelitian ini menggunakan metode swab sehingga jumlah bakteri pada setiap cawan petri tidaklah seragam. 
Pada penelitian ini menggunakan metode swab (ulas) karena saat melakukan penelitian pendahuluan dengan menggunakan metode pengenceran bakteri yang akan dicampurkan pada media SS layer bagian atas untuk pengujian antibakteri, bakteri yang tumbuh tidak memiiki ciri-ciri seperti bakteri yang diinginkan sehigga penelitian selanjutnya dilakukan dengan metode swab dimana bakteri yang telah diremajakan langsung dipindahkan kemedia untuk pengujian antibakteri dengan cara mengusapkan cotton bud dengan garis lurus dan rapat pada seluruh permukaan media yang akan digunakan. Hal ini sejalan dengan pendapat Nilamsari yang menyatakan bahwa selain komponen senyawa aktif ada beberapa hal yang mempegaruhi besar kecilnya daya hambat yang merupakan variable antibakteri antara lain konsentrasi bahan, jumlah mikroba, suhu, waktu, jenis mikroba, pH, dan bahan organic pelarut (Tri et al., 2012).

Fraksi teraktif dalam menghambat bakteri Salmonella thypi akan dilanjutkan dengan pengujian chromatogram untuk menentukan jenis senyawa. Hasil chromatogram LC-MS terdapat 61 jenis senyawa dari fraksi $\mathrm{M}_{4}$ sampel daun sirih hjau dimana komposisi terbesar yang ditemukan dari sampel daun sirih hijau ditunjukkan oleh peak number 22 dengan nama senyawa Gallic acid dengan berat molekul 170,12 pada Rt 4,277 serta memiliki formula senyawa $\mathrm{C}_{7} \mathrm{H}_{8} \mathrm{O}_{5}$. Gallic acid atau asam galat merupakan turunan dari asam hidroksibenzoat dan termasuk dalam golongan asam fenol sederhana.Senyawa fenol sendiri merupakan senyawa yang memiliki aktivitas sebagai antibakteri. Hal ini sejalan dengan pendapat Syahriastiti dan Mariyatin yang menyatakan bahwa Fenol memiliki peran menghambat aktifitas bakteri dengan cara menghambat pembentukan dinding sel dengan cara melisiskan dinding sel yang sudah terbentuk, hal ini terjadi apabila adanya interaksi antar mikroorganisme menyebabkan perubahan keseimbangan muatan dalam molekul protein, sehingga terjadinya koagulasi dan berdampak pada aktivitas fisiologi bakteri tidak dapat berfungsi dengan baik. Dengan kata lain apabila terjadi perubahan struktur protein pada dinding sel bakteri akan meningkatkan permeabilitas sel sehingga pertumbuhan sel terhambat dan menjadi rusak(Hafida et al., 2012; Syahrinastiti et al., 2015).

Selain senyawa gallic acid yang ada pada fraksi $\mathrm{M}_{4}$ terdapat pula senyawa flavonoid jenis luteolin, catechin, quercetin, rhamnetin, myricetin, luteolin 7 glucoside, quercitrin dan rutin. Kedelapan senyawa flavonoid ini juga memiliki peran sebagai antibakteri yang saling bersinergi dengan senyawa lain yang memiliki peran antibakteri sehingga fraksi $\mathbf{M}_{4}$ memiliki efektifitas antibakteri lebih besar dibandingkan dengan fraksi lainnya.

\section{SIMPULAN DAN SARAN}

Berdasarkan hasil dan kesimpulan, dari sampel daun sirih hijau keempat fraksi yang diperoleh yaitu fraksi N-Heksan, fraksi etil asetat, fraksi kloroform, fraksi methanol memiliki kandungan senyawa flavonoid dengan kadar masing-masing yaitu 51,4108 \% b/b., $47,6889 \%$ b/b., 42,9645 \% b/b., dan 41,9535 \% b/b. Fraksi teraktif dari sampel daun sirih hijau yaitu fraksi metanol dengan konsentrasi terkecil yakni 62,2 $\mu \mathrm{g} / \mathrm{ml}$ memiliki zona hambat sebesar 4,3 $\mathrm{mm}$.

Berdasarkan hasil penelitian, saran yang perlu di berikan untuk peneliti selanjutnya adalah penelitian ini dapat dilanjutkan dengan memisahkan senyawa yang dianggap paling aktif secara murni dan diuji coba antibakterinya. 


\section{DAFTAR PUSTAKA}

A, M. D., Fatimawali, \& I, W. W. (2012). Uji Aktifitas Antibakteri Ekstrak Etanol Daun Mayana (Coleus atropurpureus (L) Benth) Terhadap Staphylococcus aureus, Escherchia coli Dan Pseudomonas aeruginosa secara In-Vitro. Manado, Program Studi Farmasi FMIPA UNSRAT, 1(1), 13-21.

Ayu, A. M. (2013). Aktifitas Antibakteri Fraksi n-Heksan ekstrak etanol daginng buah sirsak (Annona muricata L) Terhadap Pseudomonas aeruginosa, Stapylococcus aureus, Shigella sonnei dan Serta Bioautografinya. Universitas Muhammadiayah Surakarta.

Hafida, M., Ekiyantini, W., \& Sri, L. (2012). Efektivitas Antibakteri Ekstrak Daun Sirih Merah (Piper Crocatum) Dan Sirih Hijau (Piper Betle L.) Sebagai Bahan Alternatif Irigasi Saluran Akar. Artikel Ilmiah Hasil Penelitian Mahasiswa Pendidikan Dokter Gigi, Fakultas Kedokteran Gigi, Universitas Jember (UNEJ), 1-4.

Haryun, N., WIdodo, E., \& Sudjarwo, E. (2017). Efek Penambahan Jus dan Daun Sirih Sebagai Aditif Pakan Terhadap Peforma Ayam Petelur. Briliant, 2(4), 429-433.

Moch, A. (2014). Efektifitas Ekstrak Daun Sirih Merah (Piper crocatum) Terhadap Kadar Hambat Minimal Dan Kadar Bunuh Minimal Bakteri Salmonella typhi. Universitas Muhammadiyah Yogyakarta.

Nirwana, P. D. (2013). Uji Aktivitas Antibakteri Ekstrak Metanol Daun Kenikir (Cosmos caudatus Kunth.) terhadap Bakteri Salmonella typhi. Universitas Islam Negeri Maulana Malik Ibrahim Malang.

Nita, N. (2013). Potensi Daun Teh (Camellia sinensis) dan Daun Antinganting Acalypha indica L. dalam Menghambat Pertumbuhan Salmonella typhi. Jurnal Al-Azhar Indonesia Seri Sains Dan Teknologi, 2(1), 104-110.

Roslizawaty, Ramadani, N. Y., Fakhrurrazi, \& Herrialfian. (2013). Aktivitas Antibakterial Ekstrak Etanol Dan Rebusan Sarang Semut (Myrmecodia Sp.)TerhadapBakteri Escherichia coli. Jurnal Medika Veterinaria, 7(2).

Syahrinastiti, A, T., Aziz, D., \& Lili, I. (2015). Perbedaan Daya Hambat Ekstrak Daun Sirih Hijau (Piper betle L) Dan Daun Sirih Merah (Piper crocatum Ruiz \& Pav) Terhadap Pertumbuhan Eschericia coli. Jurnal Kesehatan Andalas, 2(4), 421-424.

Tri, N. F., Tantin, E., \& Aju, F. D. W. (2012). Nilamsari Febriana Tri., Ermawati Tantin, F Dwi Warna Aju. 2012. Daya Hambat Ekstrak Kulit Buah Apel (Malus sylvestris Mill.) Varietas Manalagi Terhadap Pertumbuhan Streptococcus viridans(Antibacterial Activity Of Apple Peel (Malus sylvestris Mill.) Varie. Artikel Ilmiah Hasil Penelitian Mahasiswa, 1-4.

Ulviani, V., Yusriadi, \& Khaerati, H. (2016). Pengaruh Gel Ekstrak Daun Sirih Merah ( Piper Crocatum Ruiz \& Pav) Terhadap Penyembuhan Luka Bakar Pada Kelinci ( Oriyctolagus Cuniculus). Jurnal Farmasi Galenika, 2(2), 103-110. 
Widjaya, F. E., Retnani, Y., \& Hermana, W. (2018). Pengaruh Suplementasi Infusa Daun Sirih (Piperbetle L.) Terhadap Kualitas Telur Puyuh. Jurnal Ilmu Pertanian Indonesia, 23(1), 1-9.

Wilis, R., \& Andriani. (2017). Efektivitas Berkumur Rebusan Daun Sirih Dibandingkan Rebusan Daun Saga Terhadap Perubahan Derajat Keasaman Air Ludah. Action: Ac Nutrition Journal, 2(1), 67-72. 